\title{
COMMUNICATION PATTERNS IN ENGLISH CLASSES IN PUBLIC SECONDARY SCHOOLS IN BENGUET, PHILIPPINES
}

\author{
Jevera Cawilan Domogen*
}

Faculty of Teacher Education Department, Mountain Province State Polytechnic College, Tadian, Mountain

Province 2620, Philippines

\section{A RTICLE INFO}

Keywords:

Communication barriers

Communication patterns

Level of question

Article History:

Received: $14 / 01 / 2021$

Accepted: 17/05/2021

Available Online:

$31 / 05 / 2021$

\begin{abstract}
A B S T R A C T
Communication patterns assume a vital role in the English classroom. It shapes the type of discourse conveyed by the teachers and the learners. This study looked into communication patterns in English classrooms and levels of questions employed in the classroom. Communication barriers and measures to address these communication barriers were identified. The descriptive method of research was utilized in the study. The study found that the students' opportunity to express themselves is limited because the communication patterns adopted in the English classroom involve initiation-response-evaluation/feedback. Students' reasoning, creative, and critical thinking skills are not honed because of the prevalence of questions in discourse. Communication anxiety and other communication barriers directly affect the communication process. Student's success in the development of their communication skills needs to be addressed. It is recommended that teachers employ communication patterns to give learners more opportunities to express ideas. The higher levels of questions should be used in the English classroom to develop their communication skills. Teachers should also employ different learning strategies to address the communication barriers and develop learners' communication skills.
\end{abstract}

2442-305X / (C) 2021 The Author, this is open access article under the (CC-BY-NC) license (https://creativecommons.org/licenses/by-nc/4.0/), DOI: 10.19105/ojbs.v15i1.4166

\footnotetext{
$\bar{*}$ Corresponding Author:

Email address: jeveradomogenc@gmail.com (J.C. Domogen)
}

\section{A. Introduction}

Language

communication. It bridges individuals

making it a crucial element of human life.

It is a necessary tool for academic success and career advancement as well as social mobility. As Shashkevich declared in his article The power of language: How words shape people, culture, "Language is the primary tool for expression and communication that helps us better understand ourselves and why we behave the way we do."1

\footnotetext{
${ }^{1}$ Alex Shashkevich, "The Power of Language: How Words Shape People, Culture," Stanford News, August 2019 ,
} 
English, being the world's lingua franca, is essential in the global community. English equates to a job in this competitive and changing world. Mc Govern averred that English is the language of business, commerce, science, medicine, and many other key areas. ${ }^{2}$ In the English classroom, the subject serves a special purpose from that of other classrooms. It is the medium of instruction at the same time, the objective of instruction. In language teaching, the medium is the message.

Language acquisition in the English classroom requires not only meaningful interactions. Thus, communicators must be concerned with the form and the message they target to convey. It is not a set of easy steps that can be programmed in a quick-to-do-it-yourself kit. With this, awareness should be raised among students about the use of English with other non-native speakers in business and education. ${ }^{3}$

In the Philippines, as stated in the 1987 constitution, Article XIV, Section 7, for the purpose of communication and instruction, the official languages of the Philippines are Filipino and, until otherwise provided by law, English. For

https://news.stanford.edu/2019/08/22/the-power-oflanguage-how-words-shape-people-culture/.

${ }^{2}$ Kieran McGovern, "Why did English Become the 'Global Language'?," Medium, April 21, 2021, https://medium.com/english-language-faq/why-didenglish-become-the-global-language9bbc14b532cd.

${ }^{3}$ Stephanie Gross, "The Development of English as an ASEAN Lingua Franca and Its Impact on English Teaching in Vietnam," English as an International Language Journal 11, no. 1 (2016): 17, https://www.elejournals.com/eilj-2016/eilj-volume11-issue-1-may-2016/. years, Filipinos pride themselves on speaking the English language fluently. Thus, it is most widely taught in Philippine schools. It is a compulsory subject learned from elementary to tertiary level. Therefore, it comes as a surprise that Filipino learners who have been taking the subject for at least ten years find difficulty communicating the language. As reported by GMA news report in 2018, a study conducted by Hopkins International Partners revealed that college graduates from the Philippines perform lower in English than high school students in Thailand. ${ }^{4}$ The decline in English proficiency called the attention of educators as well as lawmakers to take action to this. In a Senate Resolution in 2018, Senator Grace Poe urged the conduct of an assessment to look into the decline of English skills of Filipino learners. The weakening in the English proficiency of Filipinos is also attributed to teacher's communication skills. Valderama averred that in some cases, there are educators who find difficulty in expressing themselves in English. ${ }^{5}$

A curriculum model in Philippines that began in 2013 is The $K$ to 12 . It covers Kindergarten and 12 years of basic

\footnotetext{
4 "English Proficiency of Pinoy Students, Teachers Lagging - Survey," GMA News Online, February 21, 2018, https://www.gmanetwork.com/news/news/nation/64 4114/english-proficiency-of-pinoy-studentsteachers-lagging-survey/story/.

5 Tita C. Valderama, "Pinoys' English Proficiency Declines Sharply - The Manila Times," The Manila Times, November 18, 2019, https://www.manilatimes.net/2019/11/18/opinion/col umnists/topanalysis/pinoys-english-proficiencydeclines-sharply/656784/.
} 
Education. A curriculum that visualizes graduates equipped with the necessary competencies and skills to survive in the global arena. The $\mathrm{K}$ to 12 English framework aims to help learners acquire highly-developed literacy skills to understand that the English language is the most widespread medium of communication. The curriculum used in the classroom develops higher-order thinking skills and effective communication skills that students will need in the 21st Century workplace. Therefore, the Filipino graduate is expected to be communicatively competent and multiliterate.

Communication patterns play a vital role in linguistics. In the English classroom, the process of questioning, student answering, follow-up, and evaluation, promote higher-order thinking skills. In asking questions to learners, Bloom's Taxonomy assists teachers in recognizing various levels. This system consists of six levels arranged in hierarchical form from simple to complex: remembering, understanding, applying, analyzing, evaluating, and creating.

Analyzing the use of Initiation (I), Response (R), Evaluation (E), Follow up $(F)$ in communication between the teacher and the student gives way to minimizing communication errors in the target language. Looking at the communication patterns exchanges helps Filipino learners and educators pay careful attention to the overall quality of learning. This move could find a way to modify the delivery, tailor instruction, and provide the necessary support to improve instructional delivery.
Several studies were conducted pertaining to communication patterns in the classroom. Boyd investigated the teacher's questioning patterns and their relationship with types of student talk and learning in an elementary English language learning (ELL) classroom. ${ }^{6}$ Sa'adah and Yulianti explored turn-taking used in conversation class. ${ }^{7}$ All studies indicated the type of discourse in the classroom in secondary and tertiary English classrooms.

Huo and Amir examined a classroom setting and how the 'acknowledgement tokens' are placed within the framework of teachernominated IRF sequences. ${ }^{8}$ A study conducted by Saswati sheds light that the IRF communication pattern used in the classroom can facilitate communication. ${ }^{9}$ Altas looked into turn-taking patterns in teacher talk. ${ }^{10}$ He concluded that IRE

\footnotetext{
${ }^{6}$ Maureen P. Boyd, "Relations Between Teacher Questioning and Student Talk in One Elementary ELL Classroom," Journal of Literacy Research 47, no. 3 (2015): 370-404, https://doi.org/10.1177/1086296X16632451.

7 Lailatus Sa'adah and Rani Yulianti, "Turn-Taking Used in Conversation Class: A Classroom Discourse Analysis" 1, no. 2 (2018): 17-24.

${ }^{8}$ Rizwan-ul Huq and Alia Amir, "When the Tokens Talk: IRF and the Position of Acknowledgement Tokens in Teacher-Student Talk-In-Interaction," Novitas-ROYAL (Research on Youth and Language) 9, no. 1 (2015): 60-67, http://www.divaportal.org/smash/get/diva2:925881/FULLTEXT01.p df.

9 Risna Saraswati, "Analysis of Classroom Interaction Using IRF Pattern: A Case Study of EFL Conversation Class," Journal of English Language Teaching 3, no. 1 (2018): 36, https://journal.Ippmunindra.ac.id/index.php/SCOPE/ article/download/2782/2587.

10 Betül Altaş, "Turn-Taking Patterns in Teachers Talk," International Journal of Language Academy
} 
sequence might restrict learning and turntaking forms a more intellectual environment.

Such studies impressively identified the types of discourse prevailing in the classrooms and how they may facilitate communication. However, a systematic and substantive analysis on the levels of questions asked to gain a clearer sense of what and how these question levels affect the nature of responses of learners needed to be identified and understood. This gap addressed in this paper led to identifying possible measures to respond to the communication barriers resulting from the teacher's communication pattern.

While most researches focus on the types of communication patterns in the classroom as well as communication barriers, there is a failure in connecting the communication barriers with the communication pattern prevalent in the classroom. Also, the perspective of learners on how to address these barriers is often neglected.

Thus, this study sought to identify the communication patterns in English classes, identify the level of questions employed by teachers in English classes, determine communication barriers in the English classes, identify communication strategies to minimize the communication barriers to the learning process.

\section{B. Method}

This is a descriptive research. It is concerned with evaluating the communication patterns in the English

4, no. $11 \quad$ (2016): $29-29$,

classroom interaction in the public secondary schools in Benguet, Philippines.

This study was conducted to nine public secondary schools in Benguet. There were one hundred respondents in the research study. The researcher opted to get at least $33 \%$ of the population from each school, representing the population.

The survey was utilized. The data were sorted and presented in tabular form. Descriptive and inferential statistical tools were applied to these from which conclusions were drawn, and recommendations were formulated.

The researcher utilized a survey to analyze the communication patterns in English classes comprehensively. Formulation of the survey questions resulted from poring into related literature and studies read, theories, actual observations, brainstorming sessions with colleagues in the teaching field, and regular consultation with the adviser and former instructors. The Hicks model of communication pattern was employed, and Bloom's Taxonomy of Learning Grammar was utilized. To look into the need of different communication strategies to minimize communication barriers in English classes, an interview was conducted.

The responses were sorted according to their respective categories, and then frequency counts were made. On the communication patterns, level of questions employed, and prevalence of communication barriers, the 3-point Likert scale was utilized. https://doi.org/10.18033/ijla.394. 


\section{Results}

\section{Communication Patterns in English Classes}

When teachers and learners communicate, they tend to adopt patterns of conversation organization.
The frequency of practice of the communication patterns used by the teachers in their English classes can be seen in the following table.

Table 1.

Frequency of practice of the communication patterns used by the teachers in their English classes.

\begin{tabular}{|c|c|c|c|}
\hline Communication Patterns & Mean & DE & Rank \\
\hline $\begin{array}{l}\text { 1. IR Pattern } \\
\text { Initiation - the teacher asks a question } \\
\text { Response - students answer the question }\end{array}$ & 2.15 & $\mathrm{SP}$ & 2 \\
\hline $\begin{array}{l}\text { 2. IRE/IRFe Pattern } \\
\text { Initiation - the teacher asks a question } \\
\text { Response - students answer the question } \\
\text { Evaluation/Feedback - teacher evaluates the answer }\end{array}$ & 2.75 & AP & 1 \\
\hline $\begin{array}{l}\text { 3. IRFo Pattern } \\
\text { Initiation - the teacher asks a question } \\
\text { Response - students answer the question } \\
\text { Follow-up - the teacher asks another question }\end{array}$ & 2.13 & $\mathrm{SP}$ & 3 \\
\hline Average weighted mean & 2.34 & AP & \\
\hline
\end{tabular}

Note:

\begin{tabular}{llll}
\hline Arbitrary Values & Scale & Descriptive Equivalent & Symbol \\
\hline 3 & $2.34-3.00$ & Always Practiced & $\mathrm{AP}$ \\
2 & $1.67-2.33$ & Sometimes Practiced & $\mathrm{SP}$ \\
1 & $1.00-1.66$ & Never Practiced & $\mathrm{NP}$ \\
\hline
\end{tabular}

The table revealed that the teacher always practices the IRE/IRFe pattern. The finding validates that of Wang that this pattern typifies the discourse in schooling. ${ }^{11}$ The author noted that there is a need for interactive dialog to engage students in building shared meaning. As

\footnotetext{
${ }^{11}$ Hui-Hui Wang, "Examining Patterns in TeacherStudent Classroom Conversations during STEM Lessons," Journal for STEM Education Research 3, no. 3 (2020): 69-90, https://doi.org/10.1007/s41979-019-00022-x.
}

opined by the respondents, the IRE pattern offers limited opportunities for students to verbalize their ideas further. Thoms averred that this pattern hinders the ability of the learner to respond in meaningful discourse. ${ }^{12}$ The study by Jingya investigating the IRFe cycle in

\footnotetext{
12 Joshua J. Thoms, "Classroom Discourse in Foreign Language Classrooms: A Review of the Literature," Foreign Language Annals 45, no. 1 (2012): $\quad 8-27, \quad$ https://doi.org/10.1111/j.19449720.2012.01177.x.
} 
English language classrooms revealed that this is a teacher-led discourse pattern that could control opportunities for the target language use and learning. ${ }^{13}$ This pattern which is a teacher-controlled discourse, brings the teacher as monopolizing the practice of the English language. Rustandi and Musbarok's study, "Analysis of IRF (InitiationResponse-Feedback) on Classroom Interaction in EFL Speaking Class," found out that the interaction during teachinglearning activities was full of IRFe pattern sequences. ${ }^{14}$

The IR Pattern is perceived to be sometimes practiced by English teachers. Nothing follows after the students answer the question. A respondent remarked that one does not know whether the answer is right or wrong since the interaction is limited to the teacher asking the question and the student answering. An observation noted by the respondents was the teacher ignoring the student's answers. After the student gives the response, the teacher moves on to ask a question to another student.

The least practiced among the patterns is the IRFo. It implies that English teachers are limiting students' exploring their ideas. Su mentioned that the threeturn sequence is an effective means to

\footnotetext{
${ }^{13} \mathrm{Li}$ Jingya, "Investigating the Initiation-ResponseFeedback Cycle from Moves to Discourse: A Comparative Study of Chinese and Australian English Language Classrooms" (Ph.D. Thesis, Sydney, University of New South Wales, 2018).

${ }^{14}$ Andi Rustandi, "An Analysis of IRF (InitiationResponse-Feedback) on Classroom Interaction in EFL Speaking Class," EduLite: Journal of English Education, Literature and Culture 2, no. 1 (2017): 239-50, https://doi.org/10.30659/e.2.1.239-250.
}

grasp the student's learning progress. ${ }^{15}$ The importance of follow-up to add coherence to the discussion was supported by Jaeger ${ }^{16}$ and Park et al. ${ }^{17} \mathrm{~A}$ respondent commented that if the teacher encourages the extension of responses, the class would make their thinking more visible and further open opportunities for their teacher to identify the challenges addressed in English instruction. According to Metcalfe, teachers gain valuable information from errors, and error tolerance encourages students' active, exploratory, generative engagement. ${ }^{18}$

\section{Level of questions employed by teacher in English classes}

In any classroom, teachers employ questions to assess how much is learned by the students. Table 2 shows the frequency of use of the levels of questions employed by the teachers in teaching English.

\footnotetext{
${ }^{15}$ Chien-Yuan Su, "Investigating the Effectiveness of an Interactive IRF-Based English Grammar Learning System," International Journal of Emerging Technologies in Learning (IJET) 12, no. 11 (2017): 63-82, https://onlinejournals.org/index.php/i-jet/article/view/7036.

16 Elizabeth L. Jaeger, "Initiation, Response, Follow-up and Beyond: Analyzing Dialogue Around Difficulty in a Tutorial Setting," Dialogic Pedagogy: An International Online Journal 7 (2019): 1-26, https://doi.org/10.5195/dpj.2019.195.

17 Mihwa Park et al., "Informal Formative Assessment Conversations in Mathematics: Focusing on Preservice Teachers' Initiation, Response and Follow-up Sequences in the Classroom," Eurasia Journal of Mathematics, Science and Technology Education 16, no. 10 (2020): 1-13, https://doi.org/10.29333/ejmste/8436. 18 Janet Metcalfe, "Learning from Errors," Annual Review of Psychology 68, no. 1 (2017): 465-89, https://doi.org/10.1146/annurev-psych-010416044022
} 
Table 2.

Frequency of use of level of questions employed by the teachers in English classes.

\begin{tabular}{llll}
\hline Level of Questions & Mean & DE & Rank \\
\hline 1. Remembering & 2.72 & VOU & 1 \\
2. Understanding & 2.39 & VOU & 3 \\
3. Applying & 2.17 & $\mathrm{MU}$ & 6 \\
4. Analyzing & 2.20 & $\mathrm{MU}$ & 5 \\
5. Evaluating & 2.66 & $\mathrm{VOU}$ & 2 \\
6. Creating & 2.27 & $\mathrm{MU}$ & 4 \\
\hline
\end{tabular}

Note:

\begin{tabular}{llll}
\hline $\begin{array}{l}\text { Arbitrary } \\
\text { Values }\end{array}$ & Scale & $\begin{array}{l}\text { Descriptive } \\
\text { Equivalent }\end{array}$ & Symbol \\
\hline 3 & $2.34-$ & $\begin{array}{l}\text { Very often } \\
\text { used }\end{array}$ & VOU \\
& 3.00 & Moderately & MU \\
2 & $\begin{array}{l}1.67- \\
\text { used }\end{array}$ & \\
1 & 2.33 & NU \\
& $\begin{array}{l}\text { Never } \\
\text { used }\end{array}$ & $1.00-1.66$ & \\
\hline
\end{tabular}

Chen, Hand, and Norton-Meier remarked that teacher questioning is a pivotal contributing factor that shapes the role teachers play in promoting dialogic interaction in argumentative practice and that different roles serve different functions for promoting students' conceptual understanding. ${ }^{19}$ Therefore, teachers frequently spend a great deal of classroom time testing the learner through questioning.

The study revealed that most questions asked to belong to the

19 Ying-Chih Chen, Brian Hand, and Lori NortonMeier, "Teacher Roles of Questioning in Early Elementary Science Classrooms: A Framework Promoting Student Cognitive Complexities in Argumentation," Research in Science Education 47, no. 2 (2017): 373-405, https://doi.org/10.1007/s11165-015-9506-6. remembering level. This validates Prasetyawati and Omari's study finding indicating the questions performed by an English teacher in a class to be the knowledge level. ${ }^{20} \mathrm{~A}$ teacher respondent reasoned that this is most employed to check learner's mastery of the subject matter. As further clarified by most teacher respondents, learners these days needed to be constantly reminded of the theories and the basics of the lesson as these are the bases before moving to the higher level of learning. Low mastery and understanding of the basics hinder the higher-order thinking skills development. This could also attribute to the finding on the IRE/IRFe pattern as very prevalent in the discourse patterns used in English classes where learning is limited to asking knowledge level of questions, followed by the student's response and evaluation whether right or wrong and stops there. Fitri, Syarif, and Anwar concluded in their study on the levels of questions used on reading tests that almost half of the questions are in the form of remembering. ${ }^{21}$

Understanding level came out to be very often used in the English classroom. This level which is among the lower-order thinking skills comes close to the knowledge level. Tofade, Elsner, and

\footnotetext{
${ }^{20}$ Dian Prasetyawati, "Analysis of Questions Used by English Teachers at Jakarta Intensive Learning Centre" (Thesis, South Sulawesi, Indonesia, Universitas Negeri Makassar, 2015).

21 Yenni Kurnia Fitri, Hermawati Syarif, and Desvalini Anwar, "The Levels of Questions Used on Reading Test with Regards to Revised Bloom's Taxonomy," Ta'dib 22, no. 1 (2019): 27-32, https://doi.org/10.31958/jt.v22i1.1421.
} 
Haines expressed concern that most often asked questions in the classroom belong to lower-order, convergent questions that rely on students' factual recall of prior knowledge. ${ }^{22}$

The creating level posits a level of questions using compose, construct, design, revise, create, formulate, produce, etc. This level ranked the fourth. This implies that teachers are not giving learners enough time to develop their creative thinking skills. Analyzing level yielded another low result. This level makes use of questions using analyze, take apart, draw conclusions, etc. Haber encouraged that educators must encourage and inspire critical-thinking skills among students on their own across academic subjects and in all areas of life. ${ }^{23}$

The primary purpose of determining students' success must be choosing their level of cognitive progress through wellprepared questions. Thus, the quality of questions should contribute to the development of their creativity and critical ability. Heong et al. encouraged students to acquire HOTS through the conventional teaching and learning environment or a self-instructional, individualized manual. ${ }^{24}$

22 Toyin Tofade, Jamie Elsner, and Stuart $\mathrm{T}$. Haines, "Best Practice Strategies for Effective Use of Questions as a Teaching Tool," American Journal of Pharmaceutical Education 77, no. 7 (2013): 155, https://doi.org/10.5688/ajpe777155.

${ }^{23}$ Jonathan Haber, "It's Time to Get Serious about Teaching Critical Thinking," Inside Higher Ed, March 2, 2020, https://www.insidehighered.com/views/2020/03/02/t eaching-students-think-critically-opinion.

${ }^{24}$ Yee Mei Heong et al., "The Needs Analysis of Learning Higher Order Thinking Skills for Generating Ideas," Procedia - Social and
The higher-order information is a more powerful tool in learning.

The application of cognitive level received the lowest level of question employed in English classes. Student respondents noticed that the direction of discourse pattern limits applying what is learned in the lesson. This could be attributed to the communication pattern primarily employed in the classroom. This finding agrees with the study of Assaly and Smadi where applying level received the lowest percentage in percentage in the textbook analysis in English classes. ${ }^{25}$ Contrary to this, studies by Karns, Burton, and Martin showed applying level to be most dominant. ${ }^{26}$

\section{Communication barriers in the English classes}

Communication barriers in English affect the learning processes in many ways. Table 3 presents the level of prevalence of communication barriers to the learning process.

\footnotetext{
Behavioral Sciences 59 (2012): 197-203, https://doi.org/10.1016/j.sbspro.2012.09.265.

${ }^{25}$ Ibtihal R. Assaly and Oqlah M. Smadi, "Using Bloom's Taxonomy to Evaluate the Cognitive Levels of Master Class Textbook's Questions," English Language Teaching 8, no. 5 (2015): 100110, https://doi.org/10.5539/elt.v8n5p100.

${ }^{26}$ James Karns, Gene Burton, and Gerald Martin, "Learning Objectives and Testing: An Analysis of Six Principles of Economics Textbooks, Using Bloom's Taxonomy," The Journal of Economic Education 14, no. 3 (2014): 16-20, https://doi.org/10.1080/00220485.1983.10845021.
} 
Table 3.

Level of the prevalence of communication barriers in English.

\begin{tabular}{|c|c|c|c|}
\hline $\begin{array}{l}\text { Communication } \\
\text { Barriers }\end{array}$ & Mean & DE & Rank \\
\hline $\begin{array}{l}\text { 1. Speech skill } \\
\text { deficiencies }\end{array}$ & 2.2 & MP & 5 \\
\hline $\begin{array}{l}\text { 2. Language } \\
\text { impairment }\end{array}$ & 2.03 & $\mathrm{MP}$ & 6 \\
\hline $\begin{array}{l}\text { 3. Low self- } \\
\text { confidence }\end{array}$ & 2.3 & $\mathrm{MP}$ & 4 \\
\hline $\begin{array}{l}\text { 4. Communication } \\
\text { apprehension }\end{array}$ & 2.61 & VP & 1 \\
\hline $\begin{array}{l}\text { 5. Poor reading } \\
\text { comprehension }\end{array}$ & 2.32 & MP & 3 \\
\hline $\begin{array}{l}\text { 6. Poor listening } \\
\text { comprehension }\end{array}$ & 2.57 & VP & 2 \\
\hline
\end{tabular}

Note:

\begin{tabular}{llll}
\hline $\begin{array}{l}\text { Arbitrary } \\
\text { Values }\end{array}$ & Scale & $\begin{array}{l}\text { Descriptive } \\
\text { Equivalent }\end{array}$ & Symbol \\
\hline 3 & $2.34-3.00$ & $\begin{array}{l}\text { Very } \\
\text { Prevalent }\end{array}$ & VP \\
2 & $1.67-2.33$ & $\begin{array}{l}\text { Moderately } \\
\text { Prevalent }\end{array}$ & $\mathrm{MO}$ \\
1 & $1.00-1.66$ & Prevalent & $\mathrm{P}$ \\
\hline
\end{tabular}

From the table above, rated with the highest mean to be a communication barrier in English discourse is communication apprehension. McCroskey defines communication apprehension as the "fear or anxiety associated with either real or anticipated communication with another person or persons." ${ }^{27}$ Aeni, Jabu, Rahman, and Strid confirmed in their study that the students showed the highest apprehension for public speaking. ${ }^{28}$ Respondents commented that

27 James McCroskey, An Introduction to Rhetorical Communication (Boston: Allyn \& Bacon, 2001), 40.

28 Nur Aeni et al., "English Oral Communication Apprehension in Students of Indonesian Maritime," fear of speaking in front of their class significantly affects their self-expression. Cited by the respondents on the causes of their communication apprehension are fear of criticism by their teachers and classmates, preference to written work over oral discourse, and negative evaluation.

A study by Ireland found out that the causes of fear of speaking in public to be conspicuousness, performance orientation, audience characteristics, and trait-like individual differences. ${ }^{29}$ Amara's findings on her study of Oral Communication Apprehension Among ESP Students revealed that ESP learners have a high level of communication apprehension attributed to instructional and psychological factors to the situation. ${ }^{30}$ Sari found out in a study on "Speaking anxiety as a factor in studying EFL" that communication apprehension factors lead to speaking anxiety, fear of negative evaluations, test anxiety, and anxiety about English classes. ${ }^{31}$

International Journal of English Linguistics 7, no. 4 (2017): p158, https://doi.org/10.5539/ijel.v7n4p158.

${ }^{29}$ Christopher Ireland, "Student Oral Presentations: Developing the Skills and Reducing the Apprehension," in Reducing Public Speaking Anxiety in Undergraduates: A Case Study of an Intervention with Accountancy Students (10th Annual International Technology, Education, and Development Conference INTED 2016, Valencia, Spain, 2016), https://doi.org/10.21125/inted.2016.1317.

30 Naimi Amara, "Oral Communication Apprehension Among ESP Students in Algeria. Arabic Language, Literature \& Culture (Science PG)," Arabic Language, Literature \& Culture 3, no. 3 (2018): 22-28, https://doi.org/10.11648/j.allc.20180303.11.

31 Darmaida Sari, "Speaking Anxiety as a Factor in Studying EFL," English Education Journal 8, no. 2 (2017): 177-86. 
Poor listening comprehension is seen to be a communication barrier in English class. In this study, student respondents expressed that they fail to answer the teacher's question due to the inability to deciphering the meaning of the words or sentences uttered by the teacher. Often, they resort to not answering rather than asking the teacher for clarification due to fear of criticism.

The teacher respondents also identified physical setting as a factor contributory to poor listening comprehension. In public secondary institutions with an average of 40-45 students, listening is at stake with the large number. For bigger institutions with higher Maintenance and Other Operating Expenses (MOOE) budget, the provision of lapel microphone with the speaker is utilized. The school's location is also an identified factor to poor listening comprehension, as noticed by the respondents. Several schools where the study was conducted showed buildings near the public highway with the prevalence of public utility vehicles and private-owned cars traversing. Darti and Asmawati study reported that listening is a challenging skill to develop due to factors affected by the listening material, listener factor, and physical setting. ${ }^{32}$

Respondents believed poor reading comprehension is a contributory factor in the success of discourse in the English

32 Darti and Andi Asmawati, "Analyzing Students' Difficulties toward Listening Comprehension," ETERNAL (English, Teaching, Learning, and Research Journal) 3, no. 2 (2017): 211-28, https://doi.org/10.24252/Eternal.V32.2017.A9. classroom. Student respondents remark that they fail to respond to the teacher's query after a reading session due to a lack of connection to the reading text. This implies that when learners do not understand the reading material, communication failures occur. Deutsch observed the many variables causing difficulty in reading- unfamiliar scripts, writing systems, and unfamiliar cultural material are some factors. ${ }^{33}$ Respondents commented that looking at uninteresting long texts contributes to anxiety. Students lack the confidence to enjoy reading and think that reading is just a classroom chore blocking comprehension. Like listening comprehension, respondents named the physical condition of the classroom as a factor. Concentration on reading is affected by the surrounding. Students experienced barriers to learning that was not optimally conducive to learning aside from materials that were not always engaging.

The respondents agreed that low self-confidence directly impedes success in discourse. Leong and Ahmadi named the factors affecting English speaking skills as low self-esteem and low motivation as severe problems in speaking skills in their study. Learner respondents claimed that questions requiring them to remember lessons, as well as failure to follow-up with another question, control the interest of learners. These reasons were the same as that of

\footnotetext{
${ }^{33}$ Nellie Deutsch, "ESL/EFL Students Lack the Skills to Cope with Reading Comprehension Tests" (Unpublished Master Thesis, Arizona, United States of America, University of Phoenix, 2011).
} 
Nguyen. ${ }^{34}$ Their findings revealed that lack of confidence, shyness, and particularly their feeling of losing face or sounding silly before their teacher and classmates are reasons for communication failure. Tridinanti explained that self-confidence has a significant correlation with speech achievement. ${ }^{35}$ Higher self-confidence yield higher achievement. This study's findings affirmed that of Krashen as cited in Kitiabi. $^{36} \mathrm{He}$ revealed that lowmotivated learners and with low selfconfidence are not equipped enough with second language acquisition compared to those highly motivated, self-confident learners who exhibit success in the English discourse.

\section{Communication}

strategies

to

minimize the communication
barriers to the learning process

Communication barriers need to be minimized if not completely eradicated to have a meaningful learning process in English classes. Respondents remarked that the basic methodology of further

\footnotetext{
${ }^{34}$ Nguyen Thu Hanh, "Silence Is Gold?: A Study on Students' Silence in EFL Classrooms," International Journal of Higher Education 9, no. 4 (2020): 153, https://doi.org/10.5430/ijhe.v9n4p153.

35 Gaya Tridinanti, "The Correlation between Speaking Anxiety, Self-Confidence, and Speaking Achievement of Undergraduate EFL Students of Private University in Palembang," International Journal of Education and Literacy Studies 6, no. 4 (2018):

$35-39$,

https://doi.org/10.7575/aiac.ijels.v.6n.4p.35.

${ }^{36}$ Dianah Kitiabi, "Second Language Acquisition in a Study Abroad Context: International Students' Perspectives of the Evolution of Their 'Second Language Self'" (Master's Thesis, Ohio, United States of America, Bowling Green State University, 2018).
}

explanation is still preferred to minimize communication barriers. This implies that students understand better if a problem is explained to them.

Respondents also find interest in different types of questions in the classroom. That is the employment of the different levels from Bloom's Taxonomy. A respondent commented that since she is not good at memorization, the teacher should also consider asking questions or giving activities under creating to explore her creative side. Singh and Marappan found out in their review of the importance of higher-order thinking skills that students are interested in learning creative activities, but teachers lack expertise and motivation. ${ }^{37}$

The respondents identified the use of authentic materials in English instruction aside from plain reading texts to address poor reading and listening comprehension. Kusumawardani, Santosa, and Roschsantiningsih after a literature review concluded that authentic material is a material which is not written for teaching-learning purpose, but for giving information and communicating with the user. ${ }^{38}$ These are authentic audio, video, viewing, and printed materials. Student respondents suggested that

\footnotetext{
${ }^{37}$ Charanjit Swaran Singh, "A Review of Research on the Importance of Higher Order Thinking Skills (HOTS) in Teaching English Language," Journal of Critical Review 7, no. 8 (2020): 740-47, https://doi.org/10.31838/jcr.07.08.161.

38 Rheza Kusumawardani, Riyadi Santosa, and Dewi Roschsantiningsih, "Explore the Use of Authentic Materials to Teach Reading for Junior High School," International Journal of Multicultural and Multireligious Understanding 5, no. 4 (2018): 298-307, https://doi.org/10.18415/ijmmu.v5i4.323.
} 
teachers may venture to technologyrelated materials as these are the trends and the learners' interest. Song recordings, photographs, commercials, motion pictures, brochures, etc., could stimulate the communication process between the learners and the teachers since these are the learners' interests. Losada, Insuasty, and Osorio added that reading materials such as magazines, newspapers, journals, novels, and a collection of short stories and poems in the classroom improve the learner's motivation, curiosity, and attention. ${ }^{39}$

Clue giving and follow-up are communication techniques when students fail to comprehend the listening or reading text. Amara suggested the promotion of meaningful communicative exchanges in the language classroom to sustain interest. ${ }^{40} \mathrm{~A}$ study of the employment of Initiation/Response/Follow-Up by Miao and Heining-Boynton indicated that IRF has positive effects on instructional delivery and increased student discourse. ${ }^{41}$

\footnotetext{
${ }^{39}$ César Losada, Edgar Insuasty, and Maria Jaime, "The Impact of Authentic Materials and Tasks on Students' Communicative Competence at a Colombian Language School," PROFILE Issues in Teachers' Professional Development 19, no. 1 (2017): 89-104, https://doi.org/10.15446/profile.v19n1.56763.

40 Amara, "Oral Communication Apprehension Among ESP Students in Algeria. Arabic Language, Literature \& Culture (Science PG)," 24.

41 Pei Miao and Audrey L. Heining-Boynton, "Initiation/Response/Follow-Up, and Response to Intervention: Combining Two Models to Improve Teacher and Student Performance: Initiation/Response/Follow-Up, and Response to Intervention: Combining Two Models to Improve Teacher and Student Performance," Foreign
}

The data under the communication pattern and level of questions asked in the classroom revealed that teachers dominate talk in the classroom. With this, learners stay as passive participants. Student respondents expressed dismal responses to these discourse patterns. They suggested that teachers' other activities should be employed for them to express themselves well. The teachers must adopt role-plays, debates, seminars, workshops, educational trips, and virtual technology to elicit more participation among learners. Alasmari and Ahmed found the debate to be an engaging activity for learners in developing their proficiency in the English language. ${ }^{42}$ Beidatsch and Broomhall found in their study that role-play and gaming activities increase learners' skills in understanding a particular subject content. ${ }^{43}$ Respondent also identified electronic-virtual resources, because they are non-linear and multidimensional, may offer learners a more prosperous environment for the acquisition of English than traditional materials. Mitchell and Smith further noted that these had created enormous opportunities for learners to enhance their

\footnotetext{
Language Annals 44, no. 1 (2011): 65-79, https://doi.org/10.1111/j.1944-9720.2010.01116.x.

42 Ali Alasmari and Sayed Salahuddin Ahmed, "Using Debate in EFL Classes," English Language Teaching 6, no. 1 (2013): 147-52, https://eric.ed.gov/?id=EJ1076807.

${ }^{43}$ Cedric Beidatsch and Susan Broomhall, "Is This the Past? The Place of Role- Play Exercises in Under in Undergraduate History Teaching," Journal of University Teaching and Learning Practice 7, no. 1 (2010): 7-18, https://ro.uow.edu.au/jutlp/vol7/iss 1/6.
} 
communicative abilities. ${ }^{44}$ Teachers' role is paramount to the success of communication in the classroom. As facilitators of learning, they are the directors that would pave the way to learning. Chu and Walters suggested that as teachers, it is their role to identify differences in learning styles and explore ways to address the different learning styles to ensure success in the English classroom. ${ }^{45}$

\section{Conclusions}

Based on the study's findings, it was found out that students' opportunity to express themselves is limited because the communication patterns adopted in the English classroom involve initiationresponse-evaluation/feedback. Students' reasoning, creative, and critical thinking skills are not honed because of the prevalence of remembering level of questions in discourse. Communication anxiety and other communication barriers directly affect the communication process. The development of their communication skills needed to be addressed.

From the findings and conclusion of the study, it is recommended that teachers employ communication patterns that will give more opportunities for learners to express ideas. The higher levels of questions should be used in the English classroom to develop their

\footnotetext{
${ }^{44}$ Alice Mitchell and Carol Savill Smith, The Use of Computer and Video Games for Learning (London: Learning and Skills Development Agency, 2004).

45 Yiting Chu and Lynne Walters, "The QuestionAsking Behavior of Asian Students in an American University," Journal of English as an International Language 8, no. 2 (2013): 10-29.
}

communication skills. Teachers should also employ different learning strategies to address the communication barriers and develop learners' communication skills.

\section{References}

Aeni, Nur, Baso Jabu, Muhammad Rahman, and John Strid. "English Oral Communication Apprehension in Students of Indonesian Maritime." International Journal of English Linguistics 7, no. 4 (2017): p158. https://doi.org/10.5539/ijel.v7n4p158.

Alasmari, Ali, and Sayed Salahuddin Ahmed. "Using Debate in EFL Classes." English Language Teaching 6, no. 1 (2013): 147-52. https://eric.ed.gov/?id=EJ1076807.

Altaş, Betül. "Turn-Taking Patterns in Teachers Talk." International Journal of Language Academy 4, no. 11 (2016): 29-29. https://doi.org/10.18033/ijla.394.

Amara, Naimi. "Oral Communication Apprehension Among ESP Students in Algeria. Arabic Language, Literature \& Culture (Science PG)." Arabic Language, Literature \& Culture 3, no. 3 (2018): 22-28. https://doi.org/10.11648/j.allc.20180 303.11.

Assaly, Ibtihal R., and Oqlah M. Smadi. "Using Bloom's Taxonomy to Evaluate the Cognitive Levels of Master Class Textbook's Questions." English Language Teaching 8, no. 5 (2015): 100-110. https://doi.org/10.5539/elt.v8n5p100.

Beidatsch, Cedric, and Susan Broomhall. "Is This the Past? The Place of Role- Play Exercises in Under in Undergraduate History Teaching." Journal of University Teaching and Learning Practice 7, no. 1 (2010): 7-18. https://ro.uow.edu.au/jutlp/vol7/iss1/ 6. 
Boyd, Maureen P. "Relations Between Teacher Questioning and Student Talk in One Elementary ELL Classroom." Journal of Literacy Research 47, no. 3 (2015): 370404.

https://doi.org/10.1177/1086296X16 632451.

Chen, Ying-Chih, Brian Hand, and Lori Norton-Meier. "Teacher Roles of Questioning in Early Elementary Science Classrooms: A Framework Promoting Student Cognitive Complexities in Argumentation." Research in Science Education 47, no. 2 (2017): 373-405. https://doi.org/10.1007/s11165-0159506-6.

Chu, Yiting, and Lynne Walters. "The Question-Asking Behavior of Asian Students in an American University." Journal of English as an International Language 8, no. 2 (2013): 10-29.

Darti, and Andi Asmawati. "Analyzing Students' Difficulties toward Listening Comprehension." ETERNAL (English, Teaching, Learning, and Research Journal) 3, no. 2 (2017): 211-28. https://doi.org/10.24252/Eternal.V32 .2017.A9.

Deutsch, Nellie. "ESL/EFL Students Lack the Skills to Cope with Reading Comprehension Tests." Unpublished Master Thesis, University of Phoenix, 2011.

GMA News Online. "English Proficiency of Pinoy Students, Teachers Lagging Survey," February 21, 2018. https://www.gmanetwork.com/news/ news/nation/644114/englishproficiency-of-pinoy-studentsteachers-lagging-survey/story/.

Fitri, Yenni Kurnia, Hermawati Syarif, and Desvalini Anwar. "The Levels of Questions Used on Reading Test with Regards to Revised Bloom's Taxonomy." Ta'dib 22, no. 1 (2019): 27-32.

https://doi.org/10.31958/jt.v22i1.1421.
Gross, Stephanie. "The Development of English as an ASEAN Lingua Franca and Its Impact on English Teaching in Vietnam." English as an International Language Journal 11, no. 1 (2016): 17. https://www.elejournals.com/eilj2016/eilj-volume-11-issue-1-may2016/.

Haber, Jonathan. "It's Time to Get Serious about Teaching Critical Thinking." Inside Higher Ed, March 2, 2020. https://www.insidehighered.com/vie ws/2020/03/02/teaching-studentsthink-critically-opinion.

Hanh, Nguyen Thu. "Silence Is Gold?: A Study on Students' Silence in EFL Classrooms." International Journal of Higher Education 9, no. 4 (2020): 153.

https://doi.org/10.5430/ijhe.v9n4p15 3.

Heong, Yee Mei, Jailani Md Yunos, Widad Othman, Razali Hassan, Tee Tze Kiong, and Mimi Mohaffyza Mohamad. "The Needs Analysis of Learning Higher Order Thinking Skills for Generating Ideas." Procedia - Social and Behavioral Sciences 59 (2012): 197-203. https://doi.org/10.1016/j.sbspro.201 2.09.265.

Huq, Rizwan-ul, and Alia Amir. "When the Tokens Talk: IRF and the Position of Acknowledgement Tokens in Teacher-Student Talk-inInteraction." Novitas-ROYAL (Research on Youth and Language) 9 , no. 1 (2015): 60-67. http://www.divaportal.org/smash/get/diva2:925881/ FULLTEXT01.pdf.

Ireland, Christopher. "Student Oral Presentations: Developing the Skills and Reducing the Apprehension." In Reducing Public Speaking Anxiety in Undergraduates: A Case Study of an Intervention with Accountancy Students. Valencia, Spain, 2016. https://doi.org/10.21125/inted.2016. 1317. 
Jaeger, Elizabeth L. "Initiation, Response, Follow-up and Beyond: Analyzing Dialogue Around Difficulty in a Tutorial Setting." Dialogic Pedagogy: An International Online Journal 7 (2019): $1-26$. https://doi.org/10.5195/dpj.2019.195.

Jingya, Li. "Investigating the InitiationResponse-Feedback Cycle from Moves to Discourse: A Comparative Study of Chinese and Australian English Language Classrooms." PhD Thesis, University of New South Wales, 2018.

Karns, James, Gene Burton, and Gerald Martin. "Learning Objectives and Testing: An Analysis of Six Principles of Economics Textbooks, Using Bloom's Taxonomy." The Journal of Economic Education 14, no. 3 (2014): 16-20. https://doi.org/10.1080/00220485.19 83.10845021 .

Kitiabi, Dianah. "Second Language Acquisition in a Study Abroad Context: International Students' Perspectives of the Evolution of Their 'Second Language Self'." Master's Thesis, Bowling Green State University, 2018.

Kusumawardani, Rheza, Riyadi Santosa, and Dewi Roschsantiningsih. "Explore the Use of Authentic Materials to Teach Reading for Junior High School." International Journal of Multicultural and Multireligious Understanding 5, no. 4 (2018): 298-307. https://doi.org/10.18415/ijmmu.v5i4. 323.

Losada, César, Edgar Insuasty, and Maria Jaime. "The Impact of Authentic Materials and Tasks on Students' Communicative Competence at a Colombian Language School." PROFILE Issues in Teachers' Professional Development 19, no. 1 (2017): 89-104. https://doi.org/10.15446/profile.v19n 1.56763.
McCroskey, James. An Introduction to Rhetorical Communication. Boston: Allyn \& Bacon, 2001.

McGovern, Kieran. "Why Did English Become the 'Global Language'?" Medium, April 21, 2021. https://medium.com/englishlanguage-faq/why-did-englishbecome-the-global-language9bbc14b532cd.

Metcalfe, Janet. "Learning from Errors." Annual Review of Psychology 68, no. 1 (2017): 465-89. https://doi.org/10.1146/annurevpsych-010416-044022.

Miao, Pei, and Audrey L. HeiningBoynton.

"Initiation/Response/Follow-Up, and Response to Intervention: Combining Two Models to Improve Teacher and Student Performance: Initiation/Response/Follow-Up, and Response to Intervention: Combining Two Models to Improve Teacher and Student Performance." Foreign Language Annals 44, no. 1 (2011): 65-79. https://doi.org/10.1111/j.19449720.2010.01116.x.

Mitchell, Alice, and Carol Savill Smith. The Use of Computer and Video Games for Learning. London: Learning and Skills Development Agency, 2004.

Park, Mihwa, Minju Yi, Raymond Flores, and Bangtam Nguyen. "Informal Formative Assessment Conversations in Mathematics: Focusing on Preservice Teachers' Initiation, Response and Follow-up Sequences in the Classroom." Eurasia Journal of Mathematics, Science and Technology Education 16, no. 10 (2020): 1-13. https://doi.org/10.29333/ejmste/8436.

Prasetyawati, Dian. "Analysis of Questions Used by English Teachers at Jakarta Intensive Learning Centre." Thesis, Universitas Negeri Makassar, 2015. 
Rustandi, Andi. "An Analysis of IRF (Initiation-Response-Feedback) on Classroom Interaction in EFL Speaking Class." EduLite: Journal of English Education, Literature and Culture 2, no. 1 (2017): 239-50. https://doi.org/10.30659/e.2.1.239250.

Sa'adah, Lailatus, and Rani Yulianti. "Turn-Taking Used in Conversation Class: A Classroom Discourse Analysis" 1, no. 2 (2018): 17-24.

Saraswati, Risna. "Analysis of Classroom Interaction Using IRF Pattern: A Case Study of EFL Conversation Class." Journal of English Language Teaching 3, no. 1 (2018): 36. https://journal.Ippmunindra.ac.id/ind ex.php/SCOPE/article/download/27 82/2587.

Sari, Darmaida. "Speaking Anxiety as a Factor in Studying EFL." English Education Journal 8, no. 2 (April 30, 2017): 177-86.

Shashkevich, Alex. "The Power of Language: How Words Shape People, Culture." Stanford News, August 22, 2019. https://news.stanford.edu/2019/08/2 2/the-power-of-language-howwords-shape-people-culture/.

$\mathrm{Su}$, Chien-Yuan. "Investigating the Effectiveness of an Interactive IRFBased English Grammar Learning System." International Journal of Emerging Technologies in Learning (IJET) 12, no. 11 (2017): 63-82. https://onlinejournals.org/index.php/ijet/article/view/7036.

Swaran Singh, Charanjit. "A Review of Research on the Importance of Higher Order Thinking Skills (HOTS) in Teaching English Language." Journal of Critical Review 7, no. 8 (2020): $740-47$ https://doi.org/10.31838/jcr.07.08.161.
Thoms, Joshua J. "Classroom Discourse in Foreign Language Classrooms: A Review of the Literature." Foreign Language Annals 45, no. 1 (2012): 8-27. https://doi.org/10.1111/j.19449720.2012.01177.x.

Tofade, Toyin, Jamie Elsner, and Stuart T. Haines. "Best Practice Strategies for Effective Use of Questions as a Teaching Tool." American Journal of Pharmaceutical Education 77, no. 7 (2013): 155. https://doi.org/10.5688/ajpe777155.

Tridinanti, Gaya. "The Correlation between Speaking Anxiety, SelfConfidence, and Speaking Achievement of Undergraduate EFL Students of Private University in Palembang." International Journal of Education and Literacy Studies 6, no. 4 (2018): 35-39. https://doi.org/10.7575/aiac.ijels.v.6 n.4p.35.

Valderama, Tita C. "Pinoys' English Proficiency Declines Sharply - The Manila Times." The Manila Times, November 18, 2019. https://www.manilatimes.net/2019/1 1/18/opinion/columnists/topanalysis/ pinoys-english-proficiency-declinessharply/656784/.

Wang, Hui-Hui. "Examining Patterns in Teacher-Student Classroom Conversations during STEM Lessons." Journal for STEM Education Research 3, no. 3 (2020): 69-90. https://doi.org/10.1007/s41979-01900022-x. 


\section{Appendix}

Survey

Part I. Below are the communication patterns employed by teachers in English classes. Please check the frequency of practice of the communication patterns in your class.

\section{Legend}

$3 \quad$ Always Practiced

AP

2 Sometimes Practiced

SoP

$1 \quad$ Never Practices

NP

\begin{tabular}{|l|l|l|l|}
\hline \multirow{2}{*}{ Communication Patterns } & \multicolumn{2}{|c|}{ Frequency of Practice } \\
\cline { 2 - 4 } & AP & SoP & NP \\
\hline IR Pattern & & & \\
Initiation - the teacher asks a question & & & \\
Response - students answer the question & & & \\
\hline $\begin{array}{l}\text { IRE/IRFe Pattern } \\
\text { Initiation - the teacher asks a question }\end{array}$ & & & \\
Response - students answer the question & & \\
Evaluation/Feedback - teacher evaluates the answer & & & \\
\hline $\begin{array}{l}\text { IRFo Pattern } \\
\text { Initiation - the teacher asks a question } \\
\text { Response - students answer the question } \\
\text { Follow-up - the teacher asks another question }\end{array}$ & & & \\
\hline
\end{tabular}

Part II. Please check the frequency of use of the levels of questions employed by your teacher in English class.

Legend

$\begin{array}{lll}3 & \text { Very Often Used } & \text { VOU } \\ 2 & \text { Often Used } & \text { OU } \\ 1 & \text { Never Used } & \text { NU }\end{array}$

\begin{tabular}{|l|l|l|l|}
\hline \multirow{2}{*}{ Levels of Question } & \multicolumn{3}{|c|}{ Frequency of Use } \\
\cline { 2 - 4 } & VOU & OU & NU \\
\hline Remembering & & & \\
\hline Understanding & & & \\
\hline Applying & & & \\
\hline Analyzing & & & \\
\hline Evaluating & & & \\
\hline Creating & & & \\
\hline
\end{tabular}

OKARA: Jurnal Bahasa dan Sastra, Vol. 15, No. 1, May 2021 
Part III. Please check the level of the prevalence of communication barriers in your English class.

\section{Legend}

3 Very Prevalent VP

2 Moderately Prevalent MP

1 Prevalent LP

\begin{tabular}{|l|l|c|c|}
\hline \multirow{2}{*}{ Communication Barriers } & \multicolumn{3}{|c|}{ Level of Prevalence } \\
\cline { 2 - 4 } & VO & MO & P \\
\hline Speech skill deficiencies & & & \\
\hline Language impairment & & & \\
\hline Low self-confidence & & & \\
\hline Communication apprehension & & & \\
\hline Poor reading comprehension & & & \\
\hline Poor listening comprehension & & & \\
\hline
\end{tabular}

Part IV. Please write communication strategies that shall be employed by your English teacher to minimize the communication barriers to the learning process. 